\title{
Anchoring Selenido-Carbonyl Ruthenium Clusters to Functionalised Silica Xerogels
}

\author{
Daniele Cauzzi, Claudia Graiff, Roberto Pattacini, Giovanni Predieri and Antonio Tiripicchio*
}

\author{
Dipartimento di Chimica Generale ed Inorganica, Chimica Analitica, Chimica Fisica, Università di Parma, \\ Parco Area delle Scienze 17/A, 43100 Parma, Italy
}

\begin{abstract}
Xerogéis de silica contendo carbonilas metálicas polinucleares (clusters) com estrutura nido $\mathrm{Ru}_{3} \mathrm{Se}_{2}$ foram preparadas através de três rotas diferentes. A simples dispersão do cluster $\left[\mathrm{Ru}_{3}\left(\mu_{3}-\right.\right.$ $\mathrm{Se})_{2}(\mathrm{CO})_{7}\left(\mathrm{PPh}_{3}\right)_{2}$ ] pelo processo sol gel produz um material não homogêneo. Xerogéis homogêneos foram obtidos através da reação de $\left[\mathrm{Ru}_{3}\left(\mu_{3}-\mathrm{Se}\right)_{2}(\mathrm{CO})_{8}\left(\mathrm{PPh}_{3}\right)\right]$ com xerogéis funcionalizados contendo fragmentos difenilfosfino enxertados, e pela reação do $\left[\mathrm{Ru}_{3}(\mathrm{CO})_{12}\right]$ com um xerogel contendo grupos fosfinoseleneto enxertados. A reação entre $\left[\mathrm{Ru}_{3}(\mathrm{CO})_{12}\right]$ e seleneto de dodecildifenilfosfinoseleneto resultou na formação de quatro clusters contendo ligantes carbonil e seleneto, solúveis em solventes apolares e que podem ser empregados na confecção de filmes.
\end{abstract}

Silica Xerogels containing carbonyl $\mathrm{Ru}_{3} \mathrm{Se}_{2}$ nido clusters were prepared in three different ways. The simple dispersion of $\left[\mathrm{Ru}_{3}\left(\mu_{3}-\mathrm{Se}\right)_{2}(\mathrm{CO})_{7}\left(\mathrm{PPh}_{3}\right)_{2}\right]$ via sol gel process produces an inhomogeneous material; by contrast, homogeneous xerogels were obtained by reaction of $\left[\mathrm{Ru}_{3}\left(\mu_{3}-\mathrm{Se}\right)_{2}(\mathrm{CO})_{8}\left(\mathrm{PPh}_{3}\right)\right]$ with functionalised xerogels containing grafted diphenylphosphine moieties and by reaction of $\left[\mathrm{Ru}_{3}(\mathrm{CO})_{12}\right]$ with a xerogel containing grafted phosphine-selenide groups. The reaction between $\left[\mathrm{Ru}_{3}(\mathrm{CO})_{12}\right]$ and dodecyldiphenylphosphine selenide led to the formation of four selenido carbonyl clusters, which are soluble in hydrocarbon solvents and can be deposited as thin films from their solution by slow evaporation.

Keywords: selenium, ruthenium, carbonyl clusters, sol-gel, anchored clusters

\section{Introduction}

Transition metal species may combine with main group elements or related molecular fragments affording a variety of interesting cluster compounds. Apart from their fundamental significance as a class of complexes owning peculiar chemical and structural properties, the growing interest for these species derives from their potential applications as catalysts, electrocatalysts and precursors for semiconductors. ${ }^{1-3}$ Very recently chalcogenide ruthenium derivatives have shown interesting catalytic activity in oxygen reduction reactions in polymer electrolyte fuel cells suggesting their application as cathode for these devices. ${ }^{4-7}$ The availability of substituted chalcogenido metal clusters, such as $\left[\mathrm{M}_{\mathrm{x}} \mathrm{E}_{\mathrm{y}}(\mathrm{CO})_{\mathrm{z}}\left(\mathrm{PR}_{3}\right)_{\mathrm{w}}\right]$, offers the opportunity to obtain, by stoichiometrically and kinetically controlled processes, extended inorganic solids like $\mathrm{M}_{\mathrm{x}} \mathrm{E}_{\mathrm{y}}$ in the form of pure phases or microinhomogeneous materials (nanocomposites). ${ }^{8}$

\footnotetext{
*e-mail: tiri@unipr.it
}

In order to prepare transition-metal selenido clusters, different synthetic routes are presently available, such as those involving, as starting materials, diphenyl diselenide,,${ }^{9,10}$ phenylselenyl chloride,${ }^{11}$ selenophene, ${ }^{12}$ trialkylsilyl selenides, ${ }^{13-15}$ polyselenide anions ${ }^{16,17}$ and phosphine selenides. ${ }^{18-21}$ Furthermore small selenido clusters, such as $\left[\mathrm{M}_{2}\left(\mu-\mathrm{Se}_{2}\right)(\mathrm{CO})_{6}\right]$ and $\left[\mathrm{M}_{3}\left(\mu_{3}-\mathrm{Se}\right)_{2}(\mathrm{CO})_{9}\right]$, can be conveniently used to prepare larger mono- and bimetallic species. ${ }^{22,23}$

The reactions of tertiary phosphine selenides with metal carbonyl species provide simple synthetic procedures to form selenido clusters through transfer of selenium atoms to low-valent metal centres, taking advantage of the frailty of the $\mathrm{P}=\mathrm{Se}$ bond. Despite to its synthetic potentiality, this method has been explored only to a limited extent before the last years. For this reason, we started to study the reactions of tertiary phosphine and diphosphine selenides with $\left[\mathrm{M}_{3}(\mathrm{CO})_{12}\right](\mathrm{M}=\mathrm{Fe}$ or $\mathrm{Ru})$ with the aim to obtain new phosphine-substituted selenido-carbonyl iron and ruthenium clusters. ${ }^{24}$

These reactions give a variety of such selenido carbonyl clusters, whose structural frameworks are shown in Scheme 


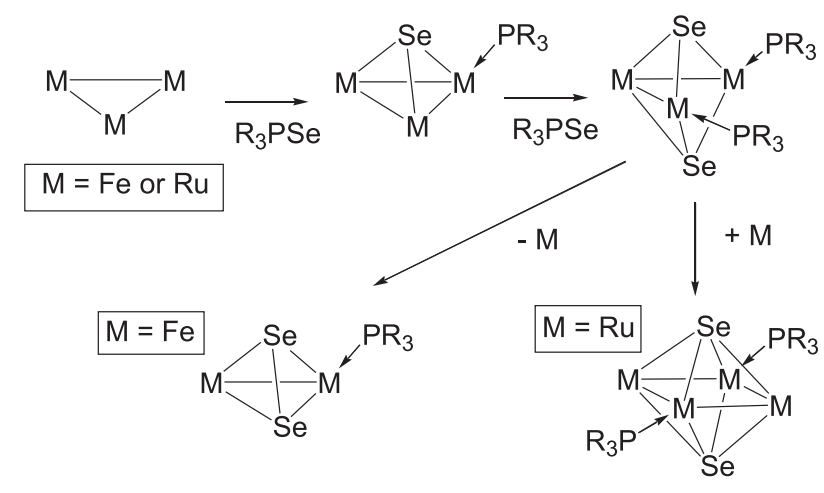

Scheme 1.

1. The open-triangular, variously substituted, nido-clusters with the $\mathrm{M}_{3} \mathrm{Se}_{2}$ core are the major products for both metals, but significant amounts of clusters with dinuclear $\mathrm{M}_{2} \mathrm{Se}_{2}$, trinuclear $\mathrm{M}_{3} \mathrm{Se}$ and tetranuclear $\mathrm{M}_{4} \mathrm{Se}_{2}$ cores are also obtained. The product distribution is strongly dependent on the reaction conditions, on the nature of the phosphine and on the cluster/phosphine molar ratio. In the case of $\left[\mathrm{Ru}_{3}(\mathrm{CO})_{12}\right]$ the reactions with $\mathrm{R}_{3} \mathrm{PSe}$ proceed through two consecutive steps, the monoselenido clusters $\left[\mathrm{Ru}_{3}\left(\mu_{3}\right.\right.$ $\left.\mathrm{Se})\left(\mu_{3}-\mathrm{CO}\right)(\mathrm{CO})_{8}\left(\mathrm{PR}_{3}\right)\right]$ undergoing the second attack by $\mathrm{R}_{3} \mathrm{PSe}$ to form the corresponding diselenido derivatives $\left[\mathrm{Ru}_{3}\left(\mu_{3}-\mathrm{Se}\right)_{2}(\mathrm{CO})_{7}\left(\mathrm{PR}_{3}\right)_{2}\right] .^{25}$

As an extension of these investigations, we have tried to produce homogeneous dispersions of selenido-carbonyl clusters into inorganic or hybrid inorganic-organic matrices through the sol-gel process. This paper deals with the description of these materials aimed to act as precursors for finely dispersed chalcogenido nanoparticles. In this regard, this is the first time that chalcogenido-carbonyl molecular clusters are dispersed into solid matrices through anchoring with grafted phosphine ligands. Previous studies on cluster anchoring via phosphorus ligands concerned only carbonyl mono- and bimetallic clusters. ${ }^{26}$ Moreover selenido carbonyl ruthenium clusters substituted with dodecyldiphenylphosphine (dodp) were prepared with the aim of obtaining selenido clusters soluble in hydrocarbons.

\section{Experimental}

\section{General procedures}

The starting reagents $\left[\mathrm{Ru}_{3}(\mathrm{CO})_{12}\right], \mathrm{KSeCN}$, elemental selenium, $\mathrm{Ph}_{2} \mathrm{PCH}_{2} \mathrm{CH}_{2} \mathrm{Si}(\mathrm{OEt})_{3}$, tetramethyl orthosilicate (TMOS), $\mathrm{NH}_{4} \mathrm{~F}$, n-dodecyl bromide, metallic $\mathrm{Mg}$ and $\mathrm{Ph}_{2} \mathrm{PCl}$ were pure commercial products (Aldrich and Fluka) and were used as received. $\left[\mathrm{Ru}_{3}\left(\mu_{3}-\mathrm{Se}\right)_{2}(\mathrm{CO})_{7}\left(\mathrm{PPh}_{3}\right)_{2}\right]$ and $\left[\mathrm{Ru}_{3}\left(\mu_{3}-\mathrm{Se}\right)_{2}(\mathrm{CO})_{8}\left(\mathrm{PPh}_{3}\right)\right]$ were prepared by reaction of
$\left[\mathrm{Ru}_{3}(\mathrm{CO})_{12}\right]$ with $\mathrm{Ph}_{3} \mathrm{PSe}$ as reported in the literature. ${ }^{24}$ The solvents (Carlo Erba) were dried and distilled by standard techniques before use. All manipulations were carried out under dry nitrogen by means of standard Schlenk-tube techniques. TLC was carried out on 20x20 silica (Merck $\left.60 \mathrm{PF}_{254}\right)$ plates. Elemental analyses $(\mathrm{C}, \mathrm{H})$ were performed with a Carlo Erba EA 1108 automated analyser. FTIR spectra ( $\mathrm{KBr}$ discs and $\mathrm{CH}_{2} \mathrm{Cl}_{2}$ solutions) were recorded on a Nicolet Nexus FT spectrometer. ${ }^{1} \mathrm{H}$ and ${ }^{31} \mathrm{P}$ NMR spectra were recorded on AC300 $\left({ }^{1} \mathrm{H}\right)$ and $\mathrm{CXP} 200\left({ }^{31} \mathrm{P}\right)$ Bruker spectrometers.

Dispersion of $\left.\mathrm{Ru} u_{3}\left(\mu_{3}-\mathrm{Se}\right)_{2}(\mathrm{CO})_{7}(\mathrm{PPh})_{2}\right)_{2}$ in silica gel by solgel process

$300 \mathrm{mg}$ of $\left[\mathrm{Ru}_{3}\left(\mu_{3}-\mathrm{Se}\right)_{2}(\mathrm{CO})_{7}\left(\mathrm{PPh}_{3}\right)_{2}\right](0.25 \mathrm{mmol})$ were dissolved in $5 \mathrm{~mL}$ of a $1: 1 \mathrm{CH}_{2} \mathrm{Cl}_{2} / \mathrm{MeOH}$ mixture and added to $270.28 \mathrm{mg}$ of TMOS (1.77 mmol). $128 \mu \mathrm{L}$ of a $0.55 \mathrm{~mol} \mathrm{~L}^{-1}$ solution of $\mathrm{NH}_{4} \mathrm{~F}$ in water were added to the first solution under stirring. After $15 \mathrm{~min}$ the gelation process was complete. $24 \mathrm{~h}$ after the gelation, due to the evaporation of $\mathrm{CH}_{2} \mathrm{Cl}_{2}$, the gel became inhomogeneous and orange crystalline formations were observed. FTIR $v_{\mathrm{CO}} / \mathrm{cm}^{-1}: 2042 \mathrm{~s}, 2009 \mathrm{~s}, 1996 \mathrm{~s}, 1980 \mathrm{~s}, 1961 \mathrm{~s}, 1948 \mathrm{~s}$ $(\mathrm{KBr})$.

\section{Preparation of the functionalized xerogel Xgpl}

A mixture of $\mathrm{Ph}_{2} \mathrm{PCH}_{2} \mathrm{CH}_{2} \mathrm{Si}(\mathrm{OEt})_{3}(590 \mathrm{mg}, 1.57 \mathrm{mmol})$ and TMOS (1187 mg, $7.80 \mathrm{mmol}$ ) was dissolved in $5 \mathrm{~mL}$ of $\mathrm{MeOH}$. A solution of $14 \mathrm{mg}$ of $\mathrm{NH}_{4} \mathrm{~F}(0.38 \mathrm{mmol})$ in $325 \mu \mathrm{L}$ of distilled water was added to the mixture under stirring. The gelation process was complete in a few seconds. The white product was filtered, washed twice with $\mathrm{MeOH}$ and dried under vacuum.

The xerogel was characterised by FTIR spectroscopy $\left(\mathrm{CH}_{2} \mathrm{CH}_{2} \mathrm{PPh}_{2}\right.$ group). FTIR $v_{\mathrm{CO}} / \mathrm{cm}^{-1}: 592 \mathrm{~s}, 740 \mathrm{~m}, 793 \mathrm{w}$, 952s, 1409w, 1436s, 1483w (KBr). Found: C, 28.8\%; H, $2.35 \%$. Anal. Calc. for $5 \mathrm{SiO}_{2} \mathrm{SiO}_{3 / 2}\left(\mathrm{CH}_{2}\right)_{2} \mathrm{PPh}_{2}: \mathrm{C}, 29.72 \%$; $\mathrm{H}, 2.49 \%$.

\section{Selenuration of Xgp1}

$500 \mathrm{mg}$ of $\mathrm{KSeCN}(3.47 \mathrm{mmol})$ were added to a suspension of Xgp1 (1.5 g) in $50 \mathrm{~mL}$ of MeCN. The mixture was stirred for $5 \mathrm{~h}$, the solvent was removed by filtration and the white solid obtained (Xgp2) was washed with amounts of $\mathrm{MeCN}$ and distilled water. FTIR spectra in $\mathrm{KBr}$ disc confirmed the selenuration: FTIR $v_{\mathrm{PSe}_{\mathrm{e}}} / \mathrm{cm}^{-1}$ : 532 (KBr). Found: C, 26.2\%; H, 2.28\%. Anal. Calc. for $5 \mathrm{SiO}_{2} \mathrm{SiO}_{3 / 2}\left(\mathrm{CH}_{2}\right)_{2} \mathrm{P}(\mathrm{Se}) \mathrm{Ph}_{2}: \mathrm{C}, 26.08 \% ; \mathrm{H}, 2.18 \%$. 
Reaction $\left[\mathrm{Ru}_{3}\left(\mu_{3}-\mathrm{Se}\right)_{2}(\mathrm{CO})_{8}\left(\mathrm{PPh} \mathrm{h}_{3}\right)\right]$ with Xgpl

$225.2 \mathrm{mg}$ of Xgp1 were added to a solution of $\left[\mathrm{Ru}_{3}\left(\mu_{3}-\right.\right.$ $\left.\mathrm{Se})_{2}(\mathrm{CO})_{8}\left(\mathrm{PPh}_{3}\right)\right](300 \mathrm{mg}, 0.30 \mathrm{mmol})$ in $100 \mathrm{~mL}$ of toluene. The suspension was stirred at $60{ }^{\circ} \mathrm{C}$ for $1 \mathrm{~h}$ and filtered. The pink-red solid (Xgp3) obtained was washed with $\mathrm{CH}_{2} \mathrm{Cl}_{2}$.

FTIR $v_{\mathrm{CO}} / \mathrm{cm}^{-1}: 2046 \mathrm{~m}, 2010 \mathrm{~s}, 1998 \mathrm{vs} 1960 \mathrm{sh}$ (KBr).

Reaction of $\left[\mathrm{Ru}_{3}(\mathrm{CO})_{12}\right]$ with $\mathrm{Xgp} 2$

$1.5 \mathrm{~g}$ of Xgp2 was added to a solution of $500 \mathrm{mg}$ of $\left[\mathrm{Ru}_{3}(\mathrm{CO})_{12}\right]$. The suspension was stirred at $90{ }^{\circ} \mathrm{C}$ for $2 \mathrm{~h}$. After filtration, a reddish brown solid (Xgp4) was isolated and washed with $\mathrm{CH}_{2} \mathrm{Cl}_{2}$. The FTIR spectra of the red solid shows CO stretching bands due to anchored carbonyl clusters: FTIR $v_{\mathrm{CO}} / \mathrm{cm}^{-1}$ : 2048vs, 2010vs, 1970s, 1810w (KBr).

The remaining orange-red solution was dried in vacuum and was redissolved in $\mathrm{CH}_{2} \mathrm{Cl}_{2}$. FTIR spectra indicate the presence of unreacted $\left[\mathrm{Ru}_{3}(\mathrm{CO})_{12}\right]$ and traces of $\left[\mathrm{Ru}_{3}\left(\mu_{3}-\right.\right.$ $\left.\mathrm{Se})_{2}(\mathrm{CO})_{9}\right]$. FTIR $v_{\mathrm{CO}} / \mathrm{cm}^{-1}: 2077 \mathrm{vs}, 2053 \mathrm{~s}$ and $2020 \mathrm{~m}$ $\left(\mathrm{CH}_{2} \mathrm{Cl}_{2}\right)$. $\left[\mathrm{Ru}_{3}(\mathrm{CO})_{12}\right]$ recovered by preparative TLC: $75 \mathrm{mg}, 15 \%$.

\section{Preparation of dodecyldiphenylphosphine (dodp)}

$0.5 \mathrm{~g}$ (20 mmol) of metallic $\mathrm{Mg}$ were added to a $20 \mathrm{~mL}$ solution of n-dodecyl bromide (3.75 g, $15 \mathrm{mmol}$ ), and activated adding $250 \mu \mathrm{L}$ of 1,2-dichloroethane.

The mixture was stirred for $10 \mathrm{~min}$ and added dropwise to a solution of $\mathrm{Ph}_{2} \mathrm{PCl}(3.31 \mathrm{~g}, 15 \mathrm{mmol})$ in $250 \mathrm{ml}$ of THF at $0{ }^{\circ} \mathrm{C}$ under nitrogen atmosphere. After stirring for $2 \mathrm{~h}$ at room temperature, the solvent was removed in vacuum and the yellow solid obtained was extracted and filtered with hexane. Upon removing the solvent, a yellow lacquer was obtained (dodp, yield 88\%).

${ }^{31} \mathrm{P}\left\{{ }^{1} \mathrm{H}\right\} \mathrm{NMR}\left(\mathrm{CDCl}_{3}\right): \delta-15.9 ;{ }^{1} \mathrm{H} \mathrm{NMR}\left(\mathrm{CDCl}_{3}\right): \delta$ $1.05\left(\mathrm{t}, 3 \mathrm{H}, \mathrm{CH}_{3} \mathrm{dd},{ }^{1} \mathrm{~J}(\mathrm{H}, \mathrm{H}) 6.9 \mathrm{~Hz}\right), 1.58-1.43(\mathrm{~m}, 22 \mathrm{H}$, $\left.\mathrm{CH}_{2} \mathrm{dd}\right), 7.5-7.8$ (m, $\left.12 \mathrm{H}, \mathrm{Ph}\right)$.

Preparation of dodecyldiphenylphosphine selenide (dodpSe)

$1.85 \mathrm{~g}$ of $\mathrm{KSeCN}(12.8 \mathrm{mmol})$ were added to a $\mathrm{CH}_{2} \mathrm{Cl}_{2}$ / MeCN (20/80 mL) solution of dodp (2.3 g, $6 \mathrm{mmol})$. The mixture was stirred at room temperature for $2 \mathrm{~h}$; the solvent was removed in vacuum and the white solid obtained was washed with water, filtered and dried under vacuum (yield $84 \%)$.

FTIR $v_{\mathrm{PSe}} / \mathrm{cm}^{-1}: 531(\mathrm{KBr}) .{ }^{31} \mathrm{P}\left\{{ }^{1} \mathrm{H}\right\} \mathrm{NMR}\left(\mathrm{CDCl}_{3}\right): \delta$
$34.1{ }^{1} J(\mathrm{P}, \mathrm{Se}) 721 \mathrm{~Hz},{ }^{1} \mathrm{H} \mathrm{NMR}\left(\mathrm{CDCl}_{3}\right): \delta 0.85\left(\mathrm{t}, 3 \mathrm{H}, \mathrm{CH}_{3}\right.$ dd, $\left.{ }^{1} J(\mathrm{H}, \mathrm{H}) 6.9 \mathrm{~Hz}\right), 1.35$ (m, $\left.20 \mathrm{H}, \mathrm{CH}_{2} \mathrm{dd}\right) 2.50$ (br, $2 \mathrm{H}, \mathrm{P}-$ $\left.\mathrm{CH}_{2} \mathrm{dd}\right), 7.4-7.9$ (m, $\left.12 \mathrm{H}, \mathrm{Ph}\right)$

\section{Reaction of $\left[\mathrm{Ru}_{3}(\mathrm{CO})_{12}\right]$ with dodpSe}

Treatment of a toluene solution of $\left[\mathrm{Ru}_{3}(\mathrm{CO})_{12}\right](300$ $\mathrm{mg}, 0.47 \mathrm{mmol})$ with $406 \mathrm{mg}$ of dodpSe $(0.94 \mathrm{mmol})$ for $1.5 \mathrm{~h}$ in toluene at $90{ }^{\circ} \mathrm{C}$ gave a deep red solution, which was evaporated to dryness. The residue was redissolved in a small amount of $\mathrm{CH}_{2} \mathrm{Cl}_{2}$. Four products were isolated by TLC using a mixture of $\mathrm{CH}_{2} \mathrm{Cl} /$ hexane $(1: 1)$ as eluent: a red-orange band containing the nido cluster $\left[\mathrm{Ru}_{3}\left(\mu_{3}-\right.\right.$ $\left.\mathrm{Se})_{2}(\mathrm{CO})_{8}(\mathrm{dodp})\right](\mathbf{1})$ (yield 20\%), a red band containing the nido cluster $\left[\mathrm{Ru}_{3}\left(\mu_{3}-\mathrm{Se}\right)_{2}(\mathrm{CO})_{7}(\operatorname{dodp})_{2}\right](2)$ (yield $\left.35 \%\right)$, a purple band containing the nido cluster $\left[\mathrm{Ru}_{3}\left(\mu_{3}-\right.\right.$ $\left.\mathrm{Se})_{2}(\mathrm{CO})_{6}(\mathrm{dodp})_{3}\right](3)$ (yield 10\%) and a brown band containing the closo cluster $\left[\mathrm{Ru}_{4}\left(\mu_{4}-\mathrm{Se}\right)_{2}(\mathrm{CO})_{9}(\mathrm{dodp})_{2}\right](4)$ (yield 15\%). All products were identified by comparison of their spectroscopic data with those reported in the literature.

Cluster 1 FTIR $v_{\mathrm{CO}} / \mathrm{cm}^{-1}: 2077 \mathrm{~m}, 2044 \mathrm{~s}, 2022 \mathrm{~s}, 2006 \mathrm{~s}$, 1977sh $\left(\mathrm{CH}_{2} \mathrm{Cl}_{2}\right)$. Found: C, 37.1\%; H 3.4\%. Anal. Calc. for $\mathrm{Ru}_{3} \mathrm{Se}_{2} \mathrm{PC}_{32} \mathrm{O}_{8} \mathrm{H}_{35}: \mathrm{C}, 36.95 \% ; \mathrm{H}, 3.36 \% .{ }^{31} \mathrm{P}\left\{{ }^{1} \mathrm{H}\right\} \mathrm{NMR}$ $\left(\mathrm{CDCl}_{3}\right): \delta 46 \mathrm{br} ;{ }^{1} \mathrm{H} \mathrm{NMR}\left(\mathrm{CDCl}_{3}\right): \delta 0.88\left(\mathrm{t}, 3 \mathrm{H}, \mathrm{CH}_{3} \mathrm{dd}\right.$, $\left.{ }^{1} J(\mathrm{H}, \mathrm{H}) 6.9 \mathrm{~Hz}\right), 1.26\left(\mathrm{~m}, 20 \mathrm{H}, \mathrm{CH}_{2} \mathrm{dd}\right), 2.61$ (br, $2 \mathrm{H}, \mathrm{PCH}_{2}$ dd), 7.5-7.8 (m, $12 \mathrm{H}, \mathrm{Ph})$

Cluster 2 FTIR $v_{\mathrm{CO}} / \mathrm{cm}^{-1}: 2045 \mathrm{~s}, 2006 \mathrm{vs}, 1967 \mathrm{~s}$, $1944 \mathrm{~m}\left(\mathrm{CH}_{2} \mathrm{Cl}_{2}\right)$. Found: C, 49.2\%; H 5.2\%. Anal. Calc. for $\mathrm{Ru}_{3} \mathrm{Se}_{2} \mathrm{P}_{2} \mathrm{C}_{55} \mathrm{O}_{7} \mathrm{H}_{70}: \mathrm{C}, 48.35 \% ; \mathrm{H}, 5.16 \%$. ${ }^{1} \mathrm{H} \mathrm{NMR}$ $\left(\mathrm{CDCl}_{3}\right): \delta 0.91\left(\mathrm{t}, 6 \mathrm{H}, \mathrm{CH}_{3} \mathrm{dd},{ }^{1} J(\mathrm{H}, \mathrm{H}) 6.9 \mathrm{~Hz}\right), \delta 1.28(\mathrm{~m}$, $40 \mathrm{H}, \mathrm{CH}_{2} \mathrm{dd}$ ), $\delta 1.66$ (br, $\left.4 \mathrm{H}, \mathrm{PCH}_{2} \mathrm{dd}\right), \delta$ 7.4-7.7 (m, $24 \mathrm{H}$, $\mathrm{Ph})$.

Cluster 3 FTIR $v_{\mathrm{CO}} / \mathrm{cm}^{-1}: 2013 \mathrm{~m}, 1988 \mathrm{vs}, 1963 \mathrm{~s}$, 1943sh $\left(\mathrm{CH}_{2} \mathrm{Cl}_{2}\right)$. Found: C, 53.8\%; H 5.9\%. Anal. Calc. for $\mathrm{Ru}_{3} \mathrm{Se}_{2} \mathrm{P}_{3} \mathrm{C}_{78} \mathrm{O}_{6} \mathrm{H}_{105}: \mathrm{C}, 55.34 \% ; \mathrm{H}, 5.67 \% .{ }^{31} \mathrm{P}\left\{{ }^{1} \mathrm{H}\right\} \mathrm{NMR}$ $\left(\mathrm{CDCl}_{3}\right): \delta 34.3,35.5,42.2 ;{ }^{1} \mathrm{H} \mathrm{NMR}\left(\mathrm{CDCl}_{3}\right): \delta 0.87(\mathrm{t}, 9$ $\left.\mathrm{H}, \mathrm{CH}_{3} \mathrm{dd},{ }^{1} \mathrm{~J}(\mathrm{H}, \mathrm{H}) 6.5 \mathrm{~Hz}\right), 1.24\left(\mathrm{~m}, 60 \mathrm{H}, \mathrm{CH}_{2} \mathrm{dd}\right), 2.47$ (br, $6 \mathrm{H}, \mathrm{PCH}_{2} \mathrm{dd}$ ), 7.4-7.7 (m, $36 \mathrm{H}, \mathrm{Ph}$ ).

Cluster 4 FTIR $v_{\mathrm{CO}} / \mathrm{cm}^{-1}$ : 2037w, 2010vs, 1955m, 1840w, 1799w $\left(\mathrm{CH}_{2} \mathrm{Cl}_{2}\right)$. Found: $\mathrm{C}, 44.2 \% ; \mathrm{H} \mathrm{4.6 \%}$. Anal. Calc. for $\mathrm{Ru}_{4} \mathrm{Se}_{2} \mathrm{P}_{2} \mathrm{C}_{57} \mathrm{O}_{9} \mathrm{H}_{70}: \mathrm{C}, 44.94 \% ; \mathrm{H}, 4.63 \% .{ }^{31} \mathrm{P}\left\{{ }^{1} \mathrm{H}\right\}$ $\operatorname{NMR}\left(\mathrm{CDCl}_{3}\right): \delta 42.6 \mathrm{br} ;{ }^{1} \mathrm{H} \mathrm{NMR}\left(\mathrm{CDCl}_{3}\right): \delta 0.87(\mathrm{t}, 6 \mathrm{H}$, $\left.\mathrm{CH}_{3} \mathrm{dd},{ }^{1} J(\mathrm{H}, \mathrm{H}) 6.3 \mathrm{~Hz}\right), 1.24$ (m, 40, $\left.\mathrm{CH}_{2} \mathrm{dd}\right), 1.66$ (br, $4 \mathrm{H}$, $\left.\mathrm{PCH}_{2} \mathrm{dd}\right), 7.3-7.5(\mathrm{~m}, 48 \mathrm{H}, \mathrm{Ph})$.

\section{Results and Discussion}

Xerogels containing selenido carbonyl nido clusters of formula $\mathrm{Ru}_{3} \mathrm{Se}_{2}$ were prepared by three different ways: (i) by reaction of $\left[\mathrm{Ru}_{3}(\mathrm{CO})_{12}\right]$ with a functionalised xerogel 
containing selenised $\mathrm{CH}_{2} \mathrm{CH}_{2} \mathrm{PPh}_{3}$ groups; (ii) by reaction of $\left[\mathrm{Ru}_{3}\left(\mu_{3}-\mathrm{Se}\right)_{2}(\mathrm{CO})_{8}\left(\mathrm{PPh}_{3}\right)\right]$ with phosphinated silica; (iii) by simple dispersion of $\left[\mathrm{Ru}_{3}\left(\mu_{3}-\mathrm{Se}\right)_{2}(\mathrm{CO})_{7}\left(\mathrm{PPh}_{3}\right)_{2}\right]$ in silica by sol-gel process.

In the last case, a solution of $\left[\mathrm{Ru}_{3}\left(\mu_{3}-\mathrm{Se}\right)_{2}(\mathrm{CO})_{7}\left(\mathrm{PPh}_{3}\right)_{2}\right]$ and TMOS (5:1 Ru/Si molar ratio) in a $\mathrm{CH}_{2} \mathrm{Cl}_{2} / \mathrm{MeOH} /$ $\mathrm{H}_{2} \mathrm{O}$ mixture yielded, by hydrolysis and condensation reactions, an homogeneous ruby-red material. Nevertheless, subsequent solvent evaporation leads to the growth of $\left[\mathrm{Ru}_{3}\left(\mu_{3}-\mathrm{Se}\right)_{2}(\mathrm{CO})_{7}\left(\mathrm{PPh}_{3}\right)_{2}\right]$ microcrystals (Figure 1) that gradually separate in the monolithic bulk.

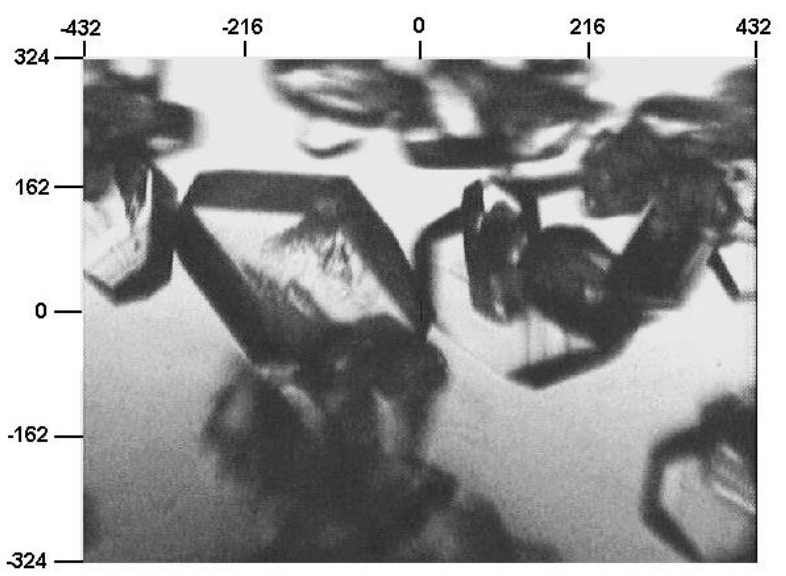

Figure 1. Microphotograph of the silica gel encapsulating $\left[\mathrm{Ru}_{3}\left(\mu_{3}-\right.\right.$ $\mathrm{Se})_{2}(\mathrm{CO})_{7}\left(\mathrm{PPh}_{3}\right)_{2}$ ] emphasizing the separation of microcrystals of the selenido cluster. The numeric values are expressed in $\mu \mathrm{m}$.

The final material is inhomogeneous and completely releases the cluster by washing with organic solvent. This occurs also in the case of a lower $\mathrm{Ru} / \mathrm{Si}$ ratio. The FTIR spectra shows strong $\mathrm{CO}$ stretching bands that perfectly superimpose the typical solid state $\left[\mathrm{Ru}_{3}\left(\mu_{3}-\right.\right.$ $\left.\mathrm{Se})_{2}(\mathrm{CO})_{7}\left(\mathrm{PPh}_{3}\right)_{2}\right]$ absorption pattern (Figure 2); these bands

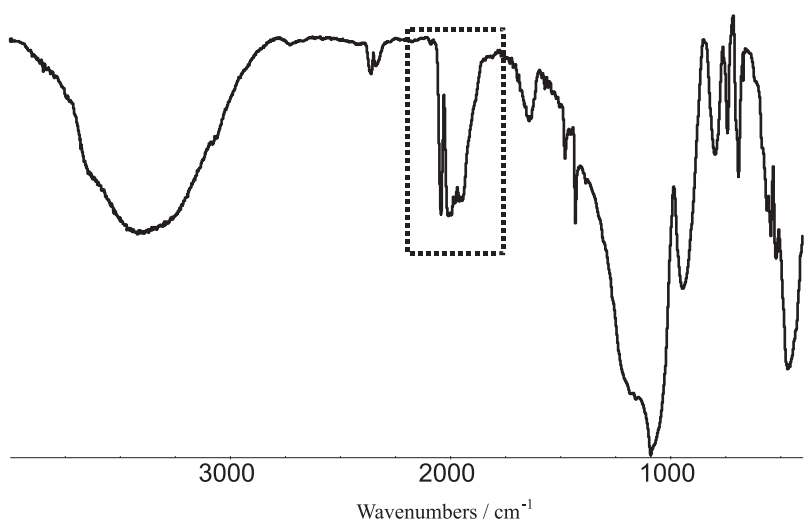

Figure 2. FTIR (transmittance \%) spectrum $(\mathrm{KBr})$ of $\left[\mathrm{Ru}_{3}\left(\mu_{3}-\right.\right.$ $\mathrm{Se})_{2}(\mathrm{CO})_{7}\left(\mathrm{PPh}_{3}\right)_{2}$ ] dispersed in silica; the $\mathrm{CO}$ stretching pattern (in the dotted rectangle) is the same observed for the pure cluster in the solid state $(\mathrm{KBr})$. disappear after washing with $\mathrm{CH}_{2} \mathrm{Cl}_{2}$, indicating the total extraction of the carbonyl cluster from the gel.

Homogeneous xerogels containing dispersed selenido clusters can be prepared by the other two ways (i and ii, mentioned above), which lead to cluster-anchoring through phosphine ligands attached to the silica. Mode (ii) involves the reaction between the molecular selenido cluster $\left[\mathrm{Ru}_{3}\left(\mu_{3}-\mathrm{Se}\right)_{2}(\mathrm{CO})_{8}\left(\mathrm{PPh}_{3}\right)\right]^{24}$ with the phosphine functionalized xerogel Xgp1. This is prepared by sol-gel co-processing TMOS and (EtO) ${ }_{3} \mathrm{SiCH}_{2} \mathrm{CH}_{2} \mathrm{PPh}_{3}(5: 1 \mathrm{Si} / \mathrm{P}$ molar ratio) in a $\mathrm{MeOH} / \mathrm{H}_{2} \mathrm{O}$ mixture. The gelation process is fast and produces an air stable material which reacts with $\left[\mathrm{Ru}_{3}\left(\mu_{3}-\mathrm{Se}\right)_{2}(\mathrm{CO})_{8}\left(\mathrm{PPh}_{3}\right)\right]$ at $60{ }^{\circ} \mathrm{C}$, yielding a purplered solid (Xgp3). The FTIR spectrum shows strong carbonyl absorption bands in the typical range of the selenido carbonyl ruthenium clusters. A comparison of the pattern with those described in the literature ${ }^{24}$ shows clearly that two species are anchored to the silica matrix: the phospine di- and tri-substituted species with the $\mathrm{Ru}_{3} \mathrm{Se}_{2}$ core (Figure 3). As one of the phosphine ligands is the original $\mathrm{PPh}_{3}$ (if we exclude its dissociation from the clusters), the di- and tri-substituted species are anchored to the gel though one and two phosphine ligands respectively.

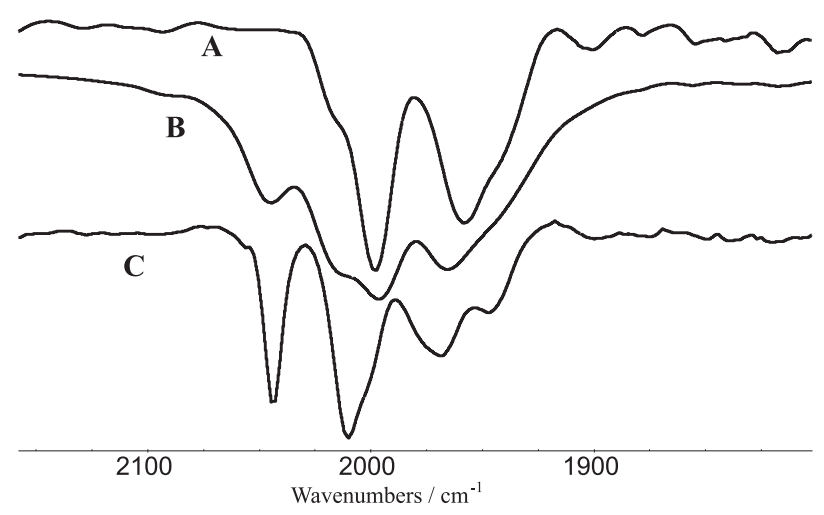

Figure 3. FTIR (transmittance \%) spectra of: A) $\left[\mathrm{Ru}_{3}\left(\mu_{3}-\right.\right.$ $\left.\left.\left.\mathrm{Se})_{2}(\mathrm{CO})_{6}\left(\mathrm{PPh}_{3}\right)_{3}\right] \quad\left(\mathrm{CH}_{2} \mathrm{Cl}_{2}\right) \quad \mathrm{B}\right) \quad \mathbf{x p g} 3 \quad(\mathrm{KBr}) \quad \mathrm{C}\right) \quad\left[\mathrm{Ru}_{3}\left(\mu_{3}-\right.\right.$ $\left.\mathrm{Se})_{2}(\mathrm{CO})_{7}\left(\mathrm{PPh}_{3}\right)_{2}\right]\left(\mathrm{CH}_{2} \mathrm{Cl}_{2}\right)$. Pattern B indicates that the $\mathbf{x p g} 3$ xerogel contains phosphine di- (pattern $\mathrm{C}$ ) and tri-substituted (pattern A) $\mathrm{Ru}_{3} \mathrm{Se}_{2}$ species.

Actually, the $\mathrm{P} / \mathrm{Si}$ molar ratio is high enough to permit that occasionally two anchored phosphine ligands coordinate two different ruthenium atoms yielding also the tri-substituted cluster, as observed for the analogous reaction between $\left[\mathrm{Ru}_{3}\left(\mu_{3}-\mathrm{Se}\right)_{2}(\mathrm{CO})_{8}\left(\mathrm{PPh}_{3}\right)\right]$ and $\mathrm{PPh}_{3}$ carried out in the liquid phase. The xerogel completely retains the cluster even if treated with $\mathrm{CH}_{2} \mathrm{Cl}_{2}$ or hot toluene.

The first route (i) to anchored selenido clusters requires the use of phosphine selenides grafted to silica. Therefore 
Xgp1 was treated with $\mathrm{KSeCN}$ at room temperature, resulting in the selenation of the grafted phosphine functions which was verified by the presence of the PSe stretching band at $532 \mathrm{~cm}^{-1}$ in the FTIR spectrum.

The selenised xerogel (Xgp2) reacts with $\left[\mathrm{Ru}_{3}(\mathrm{CO})_{12}\right]$ in hot toluene, yielding a brick-red solid Xgp4, whose FTIR spectrum shows strong carbonyl absorption as in the case of Xgp3. A comparison of the absorption pattern (see Figure 4) with those reported in literature for the selenidocarbonyl ruthenium clusters confirms that the major product is the $\mathrm{Ru}_{3} \mathrm{Se}_{2}$-core cluster, anchored to the gel via two phosphine ligands. Scheme 2 represents the idealized structural diagram of the $\mathrm{Ru}_{3} \mathrm{Se}_{2}$ cluster anchored to silica in Xgp4.

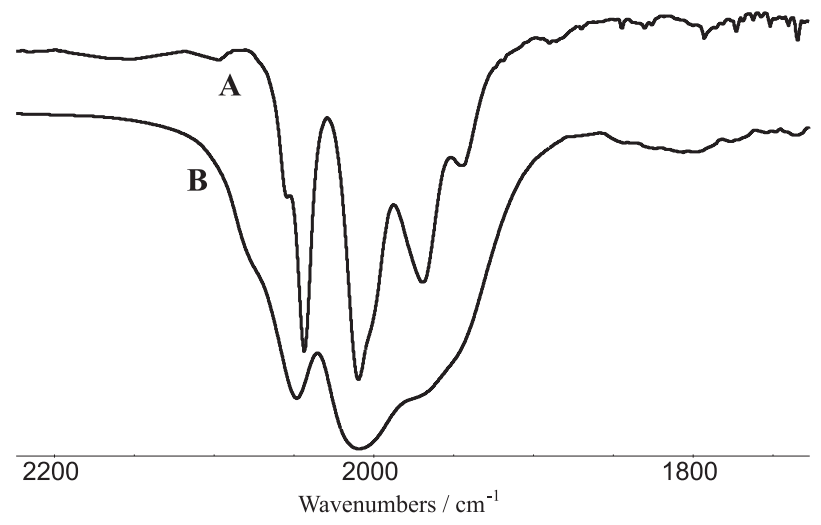

Figure 4. FTIR (transmittance \%) spectra of: A) $\left[\mathrm{Ru}_{3}\left(\mu_{3}-\right.\right.$ $\left.\mathrm{Se})_{2}(\mathrm{CO})_{7}\left(\mathrm{PPh}_{3}\right)_{2}\right]\left(\mathrm{CH}_{2} \mathrm{Cl}_{2}\right)$ B) xpg4 $(\mathrm{KBr})$ emphasizing the presence of phosphine-di-substituted $\mathrm{Ru}_{3} \mathrm{Se}_{2}$ clusters in the xerogel.

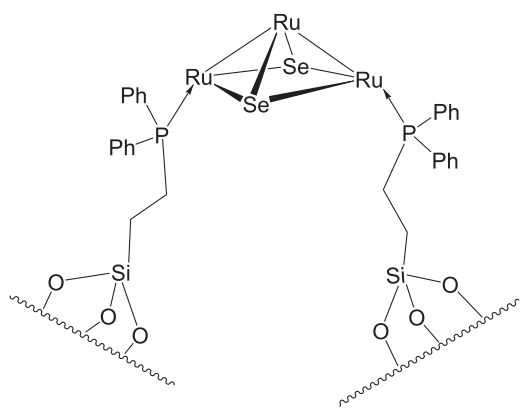

Scheme 2.

The formation of $\left[\mathrm{Ru}_{3}\left(\mu_{3}-\mathrm{Se}\right)_{2}(\mathrm{CO})_{7}(\mathrm{~L})_{2}\right] \quad(\mathrm{L}=$ $\equiv \mathrm{SiCH}_{2} \mathrm{CH}_{2} \mathrm{PPh}_{2}$ ) species is more selective than in the case of Xgp3. Despite this high selectivity, it is probable that other selenido cluster species are anchored to the gel, similarly to what observed in the reaction of $\left[\mathrm{Ru}_{3}(\mathrm{CO})_{12}\right]$ with $\mathrm{R}_{3}$ PSe in the liquid phase, which affords a variety of minor products. ${ }^{24}$ In this regard, the presence of the shoulder at $2077 \mathrm{~cm}^{-1}$ suggests the presence of the mono- substituted $\mathrm{Ru}_{3} \mathrm{Se}_{2}$ clusters, whereas the band at $1830 \mathrm{~cm}^{-1}$ is attributed to the $\left(\mu_{2}-\mathrm{CO}\right)$ stretching in the $\mathrm{Ru}_{4} \mathrm{Se}_{2}$ core clusters.

It is interesting to observe the broadening effect of the anchorage on the carbonyl stretching bands which are solution-like, broader than those observed for Xgp3 and different to the $\left[\mathrm{Ru}_{3}\left(\mu_{3}-\mathrm{Se}\right)_{2}(\mathrm{CO})_{7}\left(\mathrm{PPh}_{3}\right)_{2}\right]$ solid state pattern. The broadening effect is similar to that reported in the literature for various species anchored to silica gels. The xerogel does not release the cluster when treated with organic solvents and presents a high homogeneity, as in the case of Xgp3.

Furthermore, formation of small amounts of $\left[\mathrm{Ru}_{3}\left(\mu_{3}-\right.\right.$ $\mathrm{Se})_{2}(\mathrm{CO})_{9}$ ] in the reaction solvent should be noted from a side reaction during the anchoring process (i). This secondary reaction pattern was not observed in the case of the reaction of $\left[\mathrm{Ru}_{3}(\mathrm{CO})_{12}\right]$ with $\mathrm{R}_{3}$ PSe in liquid phases. It could be the result of selenium transfer without ligand substitution due to leaching of selenido carbonyl ruthenium species.

Finally, the reaction between dodpSe and $\left[\mathrm{Ru}_{3}(\mathrm{CO})_{12}\right]$ leads to the formation of four products: $\left[\mathrm{Ru}_{3}\left(\mu_{3}-\right.\right.$ $\left.\mathrm{Se})_{2}(\mathrm{CO})_{8}(\mathrm{dodp})\right] \mathbf{1}$ (yield 20\%), $\left[\mathrm{Ru}_{3}\left(\mu_{3}-\mathrm{Se}\right)_{2}(\mathrm{CO})_{7}(\mathrm{dodp})_{2}\right]$ 2 (yield 35\%), $\left[\mathrm{Ru}_{3}\left(\mu_{3}-\mathrm{Se}\right)_{2}(\mathrm{CO})_{6}(\right.$ dodp) 3$] 3$ (yield 10\%) and $\left[\mathrm{Ru}_{4}\left(\mu_{4}-\mathrm{Se}\right)_{2}(\mathrm{CO})_{9}(\mathrm{dodp})_{2}\right] 4$ (yield $\left.15 \%\right)$. This distribution is similar to that observed in the analogous reaction with $\mathrm{PPh}_{3}{ }^{24}$ Nido clusters $\mathbf{1}, \mathbf{2}$ and $\mathbf{3}$ contain the same square pyramidal $\mathrm{Ru}_{3} \mathrm{Se}_{2}$ core, substituted, respectively, with one, two and three phosphine ligands. Two phosphines coordinate the octahedral $\mathrm{Ru}_{4} \mathrm{Se}_{2}$ core of the closo cluster 4 . These compounds, particularly derivatives $\mathbf{2}$ and 3, are deeply coloured species soluble in hydrocarbons and easily depositable as thin films on solid surfaces by slow evaporation of their solutions; they are potential candidates for optical (NLO) applications. ${ }^{27}$

\section{References}

1. Fenske, D.; Longoni, G.; Schmid, G. In Clusters and Colloids; Schmid, G., ed., VCH: Weinheim, 1994, ch. 3, p. 89.

2. Henkel, G.; Weissgräber, S. In Metal Clusters in Chemistry; Braunstein, P.; Oro L.; Raithby P. R., eds., VCH: Weinheim, 1999, vol. 1, p. 163.

3. Dehnen, S.; Eichhöfer, A.; Fenske, D.; Eur. J. Inorg. Chem. 2002, 279.

4. Rodriguez, F. J.; Sebastian, P. J.; J. New Mat. Electrochem. Systems 1999, 2, 107.

5. Rodriguez, F. J.; Sebastian, P. J. ; Surf. Eng. 2000, 16, 43.

6. Duron, S.; Rivera-Noriega, R.; Leyva, M. A.; Nkeng, P.; Poillerat, G.; Solorza-Feria, O.; J. Solid State Electrochem. 2000, 4, 70 . 
7. Mizutani, J.; Matsumoto, K.; Chem. Lett. 2000, 1, 72.

8. Steigerwald, M. L.; Siegrist, T.; Gyorgy, E. M.; Hessen, B.; Kwon, Y.-U.; Tanzler, S. M.; Inorg. Chem. 1994, 33, 3389.

9. Johnson, B. F. G.; Layer, T. M.; Lewis, J.; Martin, A.; Raithby, P. R.; J. Organomet. Chem. 1992, 429, C41.

10. Layer, T. M.; Lewis, J.; Martin, A.; Raithby, P. R.; Wong, W.T.; J. Chem. Soc., Dalton Trans. 1992, 3411.

11. Chihara, T.; Yamazaki, H.; J. Organomet. Chem. 1992, 428, 169.

12. Arce, A. J.; Machado, R.; Rivas, C.; De Sanctis, Y.; Deeming, A. J.; J. Organomet. Chem. 1991, 419, 63.

13. Fenske, D.; Ohmer, J.; Hachgenei, J.; Angew. Chem., Int. Ed. Engl. 1985, 24, 993.

14. Fenske, D.; Krautscheid, H.; Müller, M.; Angew. Chem., Int. Ed. Engl. 1992, 31, 321.

15. Krautscheid, H.; Fenske, D.; Baum, G.; Semmelmann, M.; Angew. Chem., Int. Ed. Engl. 1993, 32, 1303.

16. Hsiou Liao, J.; Kanatzidis, M. G. ; Inorg. Chem. 1992, 31, 431.

17. Hsiou Liao, J.; Kanatzidis, M. G.; J. Am. Chem. Soc. 1990, 112,7400 .

18. Hogarth, G.; Taylor, N. J.; Carty, A. J.; Meyer, A.; J. Chem. Soc., Chem. Commun. 1988, 834.

19. Van Gastel, F.; Agnes, L.; Cherkas, A. A.; Corrigan, J. F.; Doherty, S.; Ramachandran, R.; Taylor, N. J.; and Carty, A. J.; J. Cluster Sci. 1991, 2, 131.

20. Stuczynski, S.; M. Kwon Y.-U. and Steigerwald, M. L.; J. Organomet. Chem. 1993, 449, 167.

21. Imhof, W.; Huttner, G.; J. Organomet. Chem. 1993, 448, 247.

22. Mathur, P.; Hossain, Md. M.; Rashid, R. S.; J. Organomet. Chem. 1993, 460, 83.
23. Mathur, P.; Hossain, Md. M.; Rashid, R. S.; J. Organomet. Chem. 1994, 467, 245.

24. Baistrocchi, P.; Cauzzi, D.; Lanfranchi, M.; Predieri, G.; Tiripicchio, A.; Tiripicchio Camellini, M.; Inorg. Chim. Acta 1995, 235, 173; Cauzzi, D.; Graiff, C.; Predieri, G.; Tiripicchio, A. In Metal Clusters in Chemistry; Braunstein, P.; Oro, L.; Raithby, P. R., eds., VCH: Weinheim, 1999, vol. 1, pp. 193208; Cauzzi, D.; Graiff, C.; Massera, C.; Predieri, G.; Tiripicchio, A.; Eur. J. Inorg. Chem. 2001, 721; Fabrizi de Biani, F.; Graiff, C.; Opromolla, G.; Predieri, G.; Tiripicchio, A.; Zanello, P.; J. Organomet. Chem. 2001, 637-639, 586; Braunstein, P.; Graiff, C.; Massera, C.; Predieri, G.; Rosè, J.; Tiripicchio, A.; Inorg. Chem. 2002, 41, 1372

25. Belletti, D.; Cauzzi, D.; Graiff, C.; Minarelli, A.; Pattacini, R.; Predieri, G.; Tiripicchio, A.; J. Chem. Soc., Dalton Trans. 2002, 3160.

26. Freeman, M. B.; Patrick, M. A.; Gates, B. C.; J. Catal. 1982, 73, 82; Doi, Y.; Soga, K.; Yano, K.; Ono, Y.; J. Mol. Catal. 1983, 19, 359; Lieto, J.; Wolf, M.; Matrana, B. A.; Prochazka, M.; Tesche, B.; Knoezinger, H.; Gates, B. C.; J. Phys. Chem. 1985, 89, 991; Shido, T.; Okazaki, T.; Ulla, M. A.; Fujimoto, T; Ichikawa, M.; Catal. Lett. 1993, 17, 97; Shido, T.; Okazaki, T.; Ichikawa, M.; J. Mol. Catal. A 1997, 120, 33.

27. Mathur, P.; Ghose, S.; Munkir, Md. M.; Satyanarayana, C. C. V.; Chada, R. K.; Banerjee, S.; Ravindra Kumar, G.; J. Organomet. Chem., 1998, 568, 197.

Received: December 11, 2002 Published on the web: August 1, 2003 